\title{
MORBIDITY AND MORTALITY OF PANCREATIC TUMORS UNDERGOING SURGICAL TREATMENT
}

\author{
Morbimortalidade do tratamento cirúrgico dos tumores do pâncreas
}

Luiza Bueno ZENI, Ricardo Fantazzini RUSSI, Alexandre Faleiro FIALHO, Ana Luiza Pagani FONSECA, Lyara Schaefer SOMBRIO, Igor Cunha ROCHA

From the Serviço de Cirurgia Geral, Hospital Governador Celso Ramos (General Surgery Service, Hospital Governador Celso Ramos), Florianópolis, SC, Brazil.

HEADINGS - Pancreatic neoplasms. Postoperative complications. Duodenopancreactectomy.
ABSTRACT - Background: Pancreatic cancer has a high mortality rate due to late diagnosis and aggressive behavior. The prognosis is poor, with 5 -year survival occurring in less than $5 \%$ of cases. Aim: To analyze demographic characteristics, comorbidities, type of procedure and early postoperative complications of patients with pancreatic cancer submitted to surgical treatment. Methods: Crosssectional study with analysis of 28 medical records of patients with malignant tumors of the pancreas in a 62 month. Data collection was performed from the medical records of the hospital. Results: Of the total, 53,6\% were male and the mean age was 60.25 years. According to the procedure, 53,6\% was submitted to duodenopancreactectomy the remainder to biliodigestive derivation or distal pancreatectomy. The ductal adenocarcinoma occurred in $82,1 \%$ and $92,9 \%$ of tumors were located in the pancreatic head. Early postoperative complications occurred in $64,3 \%$ of cases and the most prevalent was intra-abdominal abscess (32,1\%). Among duodenopancreactectomies $77,8 \%$ had early postoperative complications. Conclusion: Its necessary to encourage early detection of tumors of the pancreas to raise the number operations with curative intent. Refinements in surgical techniques and surgical teams can diminish postoperative complications and, so, operative morbimortality can also decrease over time.

\section{Correspondence:}

Luiza Bueno Zeni

E-mail: luizazeni@hotmail.com

Financial source: none

Conflicts of interest: none

Received for publication: 25/03/2014 Accepted for publication: 26/06/2014

DESCRTORES - Neoplasias pancreáticas Complicacões pós-operatórias. Duodenopancreactectomia.
RESUMO - Racional: O câncer de pâncreas apresenta alta taxa de mortalidade por conta do diagnóstico tardio e comportamento agressivo. O prognóstico é reservado com sobrevida de cinco anos em menos de $5 \%$ dos casos. Objetivo: Analisar as características demográficas, as comorbidades, o tipo de procedimento e as intercorrências pós-operatórias precoces dos pacientes de câncer de pâncreas submetidos ao tratamento cirúrgico. Métodos: Estudo transversal, que analisou 28 prontuários de pacientes portadores de tumores malignos do pâncreas, no período de 62 meses. A coleta de dados foi realizada a partir dos prontuários médicos do hospital. Resultados: Do total de participantes $53,6 \%$ eram do sexo masculino. A média de idade foi de 60,25 anos. Em relação ao procedimento, 53,6\% foram submetidos à duodenopancreactectomia e o restante à derivação biliodigestiva ou pancreatectomia corpocaudal. O adenocarcinoma ductal ocorreu em $82,1 \%$ e 92,9\% dos tumores estavam localizados na cabeça do pâncreas. As complicações pós-operatórias precoces ocorreram em $64,3 \%$, e a mais prevalente foi abscesso intra-abdominal (32,1\%). Entre as duodenopancreatectomias, 77,8\% apresentaram complicações pós-operatórias precoces. Conclusão: Há necessidade de se incentivar a deteç̧ão precoce dos tumores de pâncreas para que se consiga realizar mais operações com intenção curativa. Também, é necessário o aprimoramento das técnicas operatórias e das equipes cirúrgicas para que as complicações pós-operatórias e a morbimortalidade operatória diminuam ao longo do tempo.

\section{INTRODUCTION}

T he incidence of pancreatic cancer in the United States is 13.6 per 100,000 in men and 10.7 per 100,000 in women ${ }^{13}$. In Brazil, this disease is responsible for about $2 \%$ of all diagnosed cancers and $4 \%$ of all cancer deaths ${ }^{4}$. The prognosis is poor, with a 5 -year survival of less than $5 \%^{7}$.

Ductal adenocarcinoma is preferentially localized to the head of the organ(47$65 \%)$, followed by the body and tail $(15-18 \%)^{8}$. The treatment of choice is surgical ${ }^{14}$, although not all patients are candidates for this kind of treatment, in which postoperative complications occur in $33.6 \%$, most commonly due to infections (13.8\%) followed by pleural effusion $(9.8 \%)^{14}$.

Patients with pancreatic cancer have been studied and observed over a long period of time, and these studies report an increasing incidence of the disease ${ }^{30,17}$. However, there is also a study reporting a decline ${ }^{22}$. In any event, the prognosis is bleak ${ }^{10}$, but with improved long-term survival 22,30,6.

Thus, the objective of this study was to analyze the demographic characteristics, comorbidities, type of surgical procedure, and early postoperative complications in patients with pancreatic cancer undergoing surgery. 
METHODS

This cross-sectional study was performed at the General Surgery Service of the Hospital Governador Celso Ramos, Florianópolis, SC, Brazil and approved by the Committee for Ethics in Research at the hospital.

The medical records of 28 patients, who underwent surgical treatment for pancreatic tumors between January, 2008 and February, 2013, were analyzed. The patient charts were obtained from the Medical Archive Service as well as hospital electronic records. The data were recorded on a data collection instrument built exclusively for this study, containing biological and clinical variables pertaining to tumor and postoperative characteristics. All charts of patients suffering from pancreatic cancer and subjected to surgical treatment of any kind were included in the study, and those who received surgical treatment for peritoneal carcinomatosis or those with insufficient chart data were excluded.

Results were entered into the Microsoft Excel Program (OU Epi-DATA) and exported to SPSS 16 (Statistical Package for the Social Sciences 16). Data were analyzed and described as absolute and relative frequencies. The Chi-square test or Fisher's exact test was utilized to test for homogeneity of proportions. The significance level was set to a value of $p<0.05$.

\section{RESULTS}

The medical records of 28 patients were analyzed. Fifteen (53.6\%) were men. The average age was 60.25 years old (39-89). Weight varied between 44 and $90 \mathrm{~kg}$, with a mean value of $64.8 \mathrm{~kg}$. Three types of surgical procedure were studied.

The majority of patients (53.6\%) underwent duodenopancreatectomy. Biliodigestive derivations, for palliative treatment, were performed in $39.3 \%$. In both groups the neoplasms were localized to the head of the pancreas. In $7.1 \%$ of the patients, pancreatectomy of the tail and body was performed, since the neoplasm was localized to the body/tail.

Comorbidities of the participants, smoking, diabetes mellitus, alcoholism and systemic arterial hypertension were studied (Table 1).

TABLE 1 - Lifestyle factors and associated comorbidities

\begin{tabular}{|l|l|l|}
\hline Variable & N & $\%$ \\
\hline Smoking & & \\
\hline Smoker & 07 & 25.0 \\
\hline $\begin{array}{l}\text { Non-smoker } \\
\text { Ex-smoker }\end{array}$ & 15 & 53.6 \\
\hline $\begin{array}{l}\text { Diabetes melitus } \\
\text { Yes }\end{array}$ & 06 & 21.4 \\
\hline No & 09 & 32.1 \\
\hline Alcoholism & 19 & 67.9 \\
\hline Yes & & \\
\hline No & 06 & 21.4 \\
\hline Arterial hypertension & 22 & 78.6 \\
\hline Yes & & \\
\hline$\quad$ No & 11 & 39.3 \\
\hline Other & 17 & 60.7 \\
\hline
\end{tabular}

The tumor characteristics analyzed were histological type, T stage and $\mathrm{N}$ (lymph node) stage (Table 2).

Values of the tumor marker CA 19-9 were collected from 24 patients. The analysis demonstrated that $50 \%$ of the patients had values $\leq 37 \mathrm{U} / \mathrm{ml} ; 20.8 \%$, between 37.1 and $369.9 \mathrm{U} / \mathrm{ml} ; 29.2 \%, \geq 370 \mathrm{U} / \mathrm{ml}$, and $14.2 \%$ had no information concerning the marker. The values varied between 1.2 and $84476.5 \mathrm{U} / \mathrm{ml}$.
TABLE 2 - Tumor characteristics

\begin{tabular}{|l|l|l|}
\hline Variable & N & $\%$ \\
\hline Histological type & & \\
\hline Ductal adenocarcinoma & 23 & 82.1 \\
\hline Acinar carcinoma & 01 & 3.60 \\
\hline Cystic neoplasm & 01 & 3.60 \\
\hline Endocrine neoplasm & 02 & 7.10 \\
\hline Other & 01 & 3.60 \\
\hline Localization of tumor & & \\
\hline Head & 26 & 92.9 \\
\hline Body/tail & 02 & 7.10 \\
\hline T stage & & \\
\hline T1 & 04 & 15.4 \\
\hline T2 & 04 & 15.4 \\
\hline T3 & 08 & 30.7 \\
\hline T4 & 10 & 38.5 \\
\hline N stage & & \\
\hline NX & 09 & 33.3 \\
\hline N0 & 12 & 44.5 \\
\hline N1 & 06 & 22.2 \\
\hline
\end{tabular}

The most common early surgical complications were intra-abdominal abscesses (32.1\%), followed by delayed gastric emptying (25.0\%), and pancreatic fistulas (21.4\%). Among patients who underwent duodenopancreatectomy, four had a pancreatic fistula and two, pancreatic and biliary fistulas. Surgical reintervention for early postoperative complications of any kind occurred in five patients. Early nonsurgical complications that stood out were respiratory (50.0\%) - pneumonia and respiratory insufficiency - followed by cardiologic - acute myocardial infarction and atrial fibrillation - and renal - hypokalemia and metabolic acidosis (Table 3).

\section{TABLE 3 - Early postoperative complications}

\begin{tabular}{|l|l|}
\hline Complication & $\mathbf{n}(\%)$ \\
\hline Surgical & $09(32.1)$ \\
\hline Intra-abdominal abscess & $07(25.0)$ \\
\hline Delay in gastric emptying & $06(21.4)$ \\
\hline Pancreatic fistula & $05(17.9)$ \\
\hline Biliary fistula & $04(14.3)$ \\
\hline Digestive fistula & $03(10.7)$ \\
\hline Surgical wound infection & $03(10.7)$ \\
\hline Abdominal sepsis & $02(7.10)$ \\
\hline Postoperative hemorrhage & $05(17.9)$ \\
\hline Other & \\
\hline Non-surgical & $14(50.0)$ \\
\hline Respiratory & $07(25.0)$ \\
\hline Cardiologic & $07(25.0)$ \\
\hline Renal & $09(32.1)$ \\
\hline Other
\end{tabular}

Male patients experienced $55.6 \%$ of all early postoperative complications. The diabetics experienced $44.4 \%$ of the complications, and smokers, 33.3\% (Table 4).

Among participants in stage T3, 35.4\% showed complications; among T4 patients, only $17.6 \%$; and all $\mathrm{T} 1$ and $\mathrm{T} 2$ patients showed early postoperative complications. There was a statistically significant association between the size of the tumor and all early postoperative complications $(p=0.018)$ (Table 5$)$.

Among patients undergoing duodenopancreatectomies, biliodigestive derivations, and body-tail pancreatectomies, $77.8 \%, 16.7 \%$, and $5.6 \%$ showed complications, respectively. Diabetes mellitus was associated with the following postoperative complications: fistulas (the three types studied), infections (sepsis, surgical wound infections, and intra-abdominal abscesses), delayed gastric emptying and renal complications. Smoking was associated with surgical reintervention, fistulas and respiratory complications, and asthma was associated with fistulas (Table 6). 
TABLE 4 - Association of gender and comorbidities with early postoperative complications

\begin{tabular}{|c|c|c|c|c|}
\hline \multirow{3}{*}{ Variable } & \multicolumn{2}{|c|}{ Complications } & \multirow{2}{*}{ Total } & \multirow{3}{*}{$\begin{array}{c}p \\
\text { value }\end{array}$} \\
\hline & Yes & No & & \\
\hline & $n(\%)$ & $n(\%)$ & $\mathrm{n}(\%)$ & \\
\hline Gender & & & & 0.778 \\
\hline Female & $08(44.4)$ & $05(50.0)$ & $13(46.4)$ & \\
\hline Male & $10(55.6)$ & $05(50.0)$ & 15 (53.6) & \\
\hline Total & $10(100)$ & $18(100)$ & $28(100)$ & \\
\hline Smoker & & & & 0.112 \\
\hline Yes & $06(33.3)$ & 01 (10.0) & $07(25.0)$ & \\
\hline No & 07 (38.9) & $08(80.0)$ & 15 (53.6) & \\
\hline Ex-smoker & $05(27.8)$ & $01(10.0)$ & 06 (21.4) & \\
\hline Diabetes melitus & & & & 0.098 \\
\hline Yes & $08(44.4)$ & 01 (10.0) & 09 (32.1) & \\
\hline No & $10(55.6)$ & $09(90.0)$ & 19 (67.9) & \\
\hline Arterial hypertension & & & & 1.000 \\
\hline Yes & 07 (38.9) & $04(40.0)$ & $11(39.3)$ & \\
\hline No & $11(61.1)$ & $06(60.0)$ & $17(60.7)$ & \\
\hline Alcoholism & & & & 1.000 \\
\hline Yes & $04(22.2)$ & $02(20.0)$ & 06 (21.4) & \\
\hline No & $14(77.8)$ & $08(80.0)$ & $66(78.6)$ & \\
\hline
\end{tabular}

TABLE 5 - Association between tumor characteristics and early postoperative complications

\begin{tabular}{|c|c|c|c|c|}
\hline \multirow{3}{*}{ Variable } & \multicolumn{2}{|c|}{ Complications } & \multirow{2}{*}{ Total } & \multirow{3}{*}{$p$ value } \\
\hline & Yes & No & & \\
\hline & $n(\%)$ & $n(\%)$ & $n(\%)$ & \\
\hline T Stage & & & & 0.018 \\
\hline $\mathrm{T} 1$ & $04(23.5)$ & - & 04 (15.4) & \\
\hline $\mathrm{T} 2$ & $04(23.5)$ & - & 04 (15.4) & \\
\hline T3 & $06(35.4)$ & $02(22.2)$ & $08(30.7)$ & \\
\hline $\mathrm{T} 4$ & $03(17.6)$ & 07 (77.8) & $10(38.5)$ & \\
\hline $\mathrm{N}$ stage & & & & 0.570 \\
\hline$N X$ & $06(33.3)$ & $03(33.4)$ & 09 (33.3) & \\
\hline NO & $09(50.0)$ & $03(33.3)$ & $12(44.5)$ & \\
\hline N1 & $03(16.7)$ & $03(33.3)$ & $06(22.2)$ & \\
\hline Histological type & & & & 0.626 \\
\hline Ductal adenocarcinoma & $14(77.6)$ & $09(90.0)$ & $23(82.1)$ & \\
\hline Acinar neopalsm & $01(5.60)$ & - & $01(3.60)$ & \\
\hline Cystic neoplasm & $01(5.60)$ & - & $01(3.60)$ & \\
\hline Endocrine neoplasm & $01(5.60)$ & $01(10.0)$ & $02(7.10)$ & \\
\hline Other & $01(5.60)$ & - & $01(3.60)$ & \\
\hline Location & & & & 1.000 \\
\hline Head & 17 (94.4\%) & 09 (90\%) & 26 (92.9\%) & \\
\hline Body/Tail & $01(5.60 \%)$ & $01(10.0 \%)$ & $02(7.10 \%)$ & \\
\hline
\end{tabular}

TABLE 6 - Association between the type of surgery performed and early postoperative complications

\begin{tabular}{|c|c|c|c|c|}
\hline \multirow{3}{*}{ Surgical procedure } & \multicolumn{2}{|c|}{ Complications } & \multirow{2}{*}{ Total } & \multirow{3}{*}{$p$ value } \\
\hline & Yes & No & & \\
\hline & n (\%) & n (\%) & n (\%) & \\
\hline Duodenopancreatectomy & $14(77.8)$ & $01(10.0)$ & $15(53.6)$ & 0.002 \\
\hline Biliodigestive derivation & 03 (16.7) & $08(80.0)$ & $11(39.3)$ & \\
\hline Body/tail pancreatectomy & $01(5.60)$ & 01 (10.0) & $02(7.10)$ & \\
\hline Total & $18(100)$ & $10(100)$ & $28(100)$ & \\
\hline
\end{tabular}

\section{DISCUSSION}

Cancer of the pancreas is most prevalent in $\operatorname{men}^{14,17,22}$ Lowenfels and Maisonneuve attribute this to the difference in the number of smokers, which is greater in males. This difference tends to disappear due to increases in women smokers ${ }^{20}$ or the tendency of women to live longer than men ${ }^{17,9}$. Several authors point out that the predominant age of patients with pancreatic cancer is above 60 years old $14,22,18,11$. Rocha et al. ${ }^{26}$, analyzing patients in Belo Horizonte, Brazil, reported a mean age of 59 years old, coinciding with world trends.
Cancers in patients undergoing duodenopancreatectomy progressed as far as stage II-B ${ }^{29}$, and T3N1MO occurred at the highest frequency. When isolated tumors were studied, it was found that the majority (38.5\%) were grouped in stage T4. However, when the surgical procedure was analyzed, it was found that the majority of patients underwent duodenopancreatectomy because they were in stages T1-T3, that is, the sum total of the tumors staged in T1-T3 was greater than those staged exclusively in $\mathrm{T} 4$, explaining the prevalence of duodenopancreatectomy as the surgical procedure in this study rather than a palliative surgical procedure. Such data are in accordance with other studies ${ }^{14,11}$ that recommend resection up to stage II-B. However, Lefebvre et al. ${ }^{17}$ and Abraham et al. ${ }^{1}$ demonstrated a similar likelihood of curative surgical operations in their studies, at around $11 \%$.

Smoking is considered responsible for about $20-30 \%$ of pancreatic neoplasms in the western population ${ }^{16}$. Lowenfels et al. ${ }^{21}$ showed that smokers develop pancreatic cancer between three and four years before non-smokers. The smoking population has a $70 \%$ greater risk of developing a pancreatic malignancy than the non-smoking population. To stop or never start smoking is considered a preventive factor 21,25

The incidence of diabetes melitus is higher in patients with pancreatic cancer, but the relationship between diabetes and cancer is controversial. Some studies indicate that diabetes is a risk factor for the development of pancreatic cancer, while others argue that diabetes could be a manifestation of cancer already in existence. Liao et al. ${ }^{19}$ demonstrated that diabetic patients, less than two years after their initial diagnosis, have an increased incidence of pancreatic cancer. However, at longer periods following the diagnosis, patients show no significant difference. Chiari et al. ${ }^{5}$ observed that diabetes melitus can be an early manifestation of pancreatic cancer rather than a risk factor.

Preoperative alcoholic participants made up $1 / 4$ of the total, but there were no records mentioning the quantity of alcoholic beverages consumed. The International Agency for Research on Cancer published a monograph on the evaluation of carcinogenic risks to humans and concluded that there was insufficient evidence to consider alcohol a risk factor for development of pancreatic cancer ${ }^{27}$. However, Gupta et al. ${ }^{10}$ support the occurrence of pancreatic cancer in the subgroup of patients exhibiting excessive alcohol consumption, independently of smoking.

Studies demonstrate a higher incidence of adenocarcinomas in relation to other histological types ${ }^{2}$ and localization to the head of the pancreas $8,17,11$.

The tumor marker most commonly utilized in the diagnosis and prognosis of exocrine pancreatic cancer is the tumor-associated carbohydrate antigen 19-9 (CA 19-9). Around $70-90 \%$ of patients with pancreatic cancer express this marker in a manner sensitive to the stage of the disease ${ }^{25}$. It is not uncommon to find patients with small tumors but normal values of CA19-9. It is thought that the marker is elevated in only half of the patients with tumors of $2 \mathrm{~cm}$ or less $\mathrm{s}^{3}$. Kim et al. ${ }^{15}$ found that, at its cut-off value of $37 \mathrm{U} / \mathrm{ml}$, its sensitivity and specificity were $76.7 \%$ and $87.1 \%$, respectively. Patients with very high levels of CA 19-9 (more than $1000 \mathrm{U} / \mathrm{ml})$ are very likely to have inoperable cancer ${ }^{3}$.

Lermite et al. ${ }^{18}$ state that intra-abdominal abscesses are frequently associated with pancreatic and biliary fistulas. Diagnosis of a suspected fistula can be made by means of clinical data and confirmed by biochemical methods and imaging. In the present study, diagnosis of this complication was based solely on clinical observation, because the method used to confirm the diagnosis was not mentioned in the chart records, only the presence or absence of the complication. Therefore, in the diagnosis of a fistula, the characteristics of 
the drained liquid were taken into account; except in a few cases in which amylase was measured in the drained liquid, no laboratory testing or imaging was used to study this. A digestive fistula was considered one whose liquid contained gastrointestinal secretions. A biliary fistula was considered one whose liquid was yellow-brown in color with crystals in the pancreatic liquid.

Pancreatic fistulas occur in $10-15 \%$ of patients subjected to duodenopancreatectomy, in agreement with Lermite et al. ${ }^{18}$. However, as this complication depends on various factors, there are investigators who report a lower rate. Kamphues et al. ${ }^{14}$ found them in $1.4 \%$ of 442 surgically treated patients and Amico et al. ${ }^{2}$, in $50 \%$ of 54 surgically treated patients. Among the local factors related to the genesis of pancreatic fistulas, the consistency of the pancreatic remnant (soft, normal or hard) and the caliber of the pancreatic ducts are noteworthy. Subjective evaluation of the greater consistency of the pancreas, associated with ductal dilatation, contributed to a lower incidence of pancreatic fistulas ${ }^{23}$. In the indicated study, this complication was unrelated to the consistency of the gland or to the type of anastomosis used (duct-to-mucosa or telescoping of the pancreatic stump).

Delayed gastric emptying is, by definition, persistent gastric stasis requiring nasogastric aspiration for a period of at least 10 days or solid food intolerance for up to 14 postoperative days. Various factors are related to the onset of this complication, notably previous abdominal operations, diabetes, malnutrition and postoperative intra-abdominal complications ${ }^{12}$.

According to Kamphues et al. ${ }^{14}$, the most common non-surgical complication was of the cardiopulmonary type, occurring in $12.4 \%$ of the patients undergoing duodenopancreatectomy, and surgical reintervention took place in $10.3 \%$ of the cases. Already in the study of Rocha et al. ${ }^{26}$, the nonsurgical complication that occurred the most was pneumonia (12.2\%) along with surgical wound infection (12.2\%). In the present study, total early postoperative complications came to $64.3 \%$. This observation is at variance with Kamphues et al. ${ }^{14}$ and in harmony with Rocha et al. ${ }^{26}$, who obtained values of 33.6 and $58 \%$, respectively. In the study under discussion, $77.8 \%$ of the patients who underwent duodenopancreatectomy showed early complications postoperatively; among those subjected to biliodigestive derivation, only $16.7 \%$; and among the remaining patients, who underwent corpocaudal pancreatectomy, 5.6\%, Theoretically, one would expect to find a higher frequency of complications in patients undergoing duodenopancreatectomy when compared to those subjected to corpocaudal pancreatectomy. In the former case, the procedure is technically more complex, resulting in a longer period in surgery and the eventual need for a blood transfusion. In the latter case, the number of patients with tumors of the pancreatic body and tail was decidedly small, when compared with tumors of the head (based on the frequency of malignant tumors localized to the pancreas), and as a consequence, corpocaudal pancreatectomy was performed only a few times. Perhaps more instances of this procedure would reduce such a difference. A similar explanation may apply to cases in which the patients underwent biliodigestive derivation.

\section{CONCLUSION}

There is a need to encourage early detection of pancreatic tumors to increase the number of operations with curative potential. Refinements in surgical techniques and surgical teams could also diminish postoperative complications and thereby decrease operative morbimortality over time.

\section{REFERENCES}

1. Abraham A, Al-Refaie WB, Parsons HM, Dudeja V, Vickers SM, Habermann EB. Disparities in Pancreas Cancer Care. Ann Surg Oncol [Internet]. 2013 Abril [acesso em 2013 Maio 15];10434-012. Disponível em: http://www.ncbi.nlm.nih.gov/pubmed/23579872

2. Amico EC, Alves JR, João SA, Guimarães PL, Barreto EJ, Barreto LS, Costa PR, Medeiros JA. Complications after pancreatectomies: prospective study after ISGFP and ISGPS new classifications. Arq Bras Cir Dig. 2013 Jul-Sep;26(3):213-8.

3. Beger HG, Matsuno S, Cameron JL. Diseases of the Pancreas - Current Surgical Therapy. Berlin: Springer, 2008.

4. Brasil. Ministério da Saúde. Secretaria de Atenção à Saúde. Instituto Nacional de Câncer. Coordenação de Prevenção e Vigilância de Câncer. Estimativas 2008: Incidência de Câncer no Brasil. Rio de Janeiro: INCA; 2007. 94p. [acesso 2011 Nov 07]. Disponível em: http://bvsms.saude.gov.br/bvs/publicacoes/estimativa_ incidencia_cancer_2008.pdf

5. Chari ST, Leibson CL, Rabe KG, Timmons LJ, Ransom J, de Andrade M, Petersen GM. Pancreatic cancer-associated diabetes mellitus: prevalence and temporal association with diagnosis of cancer. Gastroenterology. 2008;134(1):95-101.

6. Cronin-Fenton DP, Erichsen R, Mortensen FV, Dikinis S, Norgaard $M$, Jacobsen J. Pancreatic cancer survival in central and northern Denmark from 1998 through 2009: a population-based cohort study. 2011;Clin.3(Suppl 1):19-25.

7. Dragovich T, Harris JE. Pancreatic cancer. Updated: Sep 13, 2011. [acesso 2011 Nov 07]. Disponível em: http://emedicine.medscape. com/article/280605-overview

8. Eloubeidi MA, Desmond RA, Wilcox CM, Wilson RJ, Manchikalapati P, Fouad MM, Eltoum I, Vickers SM. Prognostic factors for survival in pancreatic cancer: a population-based study. Am J Surg. 2006;192(3):322-9.

9. Guarita DR, Felga GEG, Cunha JEM, Rocha MS. Tumores do pâncreas. In Autores. Clínica médica, vol 4: doenças do aparelho digestivo, nutrição e doenças nutricionais. SP - Barueri: ed. Manole; 2009.

10. Gupta S, Wang F, Holly EA, Bracci PM. Risk of pancreatic cancer by alcohol dose, duration, and pattern of consumption, including binge drinking: a population- based study. Cancer Causes Control. 2010;21(7):1047-59.

11. Hartwig W, Hackert T, Hinz U, Gluth A, Bergmann F, StrobelO, Büchler MW, Werner J. Pancreatic Cancer Surgery in the New Millennium Better Prediction of Outcome. Ann Surg. 2011;254(2):311-9.

12. Henegouwen MB, van Gulik TM, DeWit LT, Allema JH, Rauws EAJ, Obertop H, Gouma DJ. Delayed gastric emptying after standard pancreaticoduodenectomy versus pylorus-preserving pancreaticoduodenectomy: an analysis of 200 consecutive patients. J Am Coll Surg. 1997;185(4):388-95.

13. Howlader N, Noone AM, Krapcho M, Neyman N, Aminou R, Waldron W, Altekruse SF, Kosary CL, Ruhl J, Tatalovich Z, Cho H, Mariotto A, Eisner MP, Lewis DR, Chen HS, Feuer EJ, Cronin KA, Edwards BK (eds). SEER Cancer Statistics Review, 1975-2008, National Cancer Institute. Bethesda, MD, based on November 2010 SEER data submission, posted to the SEER web site, 2011. [acesso 2011 Nov 06]. Disponível em: http://seer.cancer.gov/csr/1975_2005/

14. Kamphues $C$, Bova R, Schricke D, Hippler-Benscheidt M, Klauschen F, Stenzinger A, Seehofer D, Glanemann M, Neuhaus P, Bahra M. Postoperative Complications Deteriorate Long-Term Outcome in Pancreatic Cancer Patients. Ann Surg Oncol [Internet]. 2011 Abril [acesso em 2011 Ago 30];2041-4. Disponível em: http://www.ncbi. nlm.nih.gov/pubmed/21879265

15. Kim HJ, Kim MH, Myung SJ, Lim BC, Park ET, Yoo KS, Seo DW, Lee SK, Min YI. A new strategy for the application of CA19-9 in the differentiation of pancreaticobiliary cancer: analysis using a receiver operating characteristic curve. Am J Gastroenterol. 1999;94(7):1941-6.

16. La Torre G, de Waure C, Specchia ML, Nicolotti N, Capizzi S, Bilotta A, Clemente G, Ricciardi W. Does quality of observational studies affect the results of meta-analysis? The case of cigarette smoking and pancreatic cancer. Pancreas. 2009 Apr;38(3):241-7.

17. Lefebvre AC, Maurel J, Boutreux S, Bouvier V, Reimund JM, Launoy G, Arsene D. Pancreatic cancer: incidence, treatment and survival trends--1175 cases in Calvados (France) from 1978 to 2002. Gastroenterol Clin Biol. 2009;33(10-11):1045-51.

18. Lermite $E$, Pessaux $P$, Teyssedou C, Etienne $S$, Brehant O, Arnaud JP. Effect of preoperative endoscopic biliary drainage on infectious morbidity after pancreatoduodenectomy: a case- control study. Am J Surg. 2008;195(4):442-6. 
19. Liao KF, Lai SW, Li CI, Chen WC. Diabetes mellitus correlates with increased risk of pancreatic cancer: A population-based cohort study in Taiwan. J Gastroenterol Hepatol. 2012;27(4):709-13.

20. Lowenfels $A B$, Maisonneuve P. Epidemiology of pancreatic cancer. In Beger HG, Matsuno S, Cameron JL. Diseases of the pancreas: current surgical therapy. Germany: ed. Springer-Verlag Berlin Heidelberg; 2008:489-94.

21. Lowenfels AB, Maisonneuve P, Whitcomb DC, Lerch MM, DiMagno EP. Cigarette smoking as a risk factor for pancreatic cancer in patients with hereditary pancreatitis. JAMA. 2001 Jul 11;286(2):169-70.

22. Luke C, Price T, Karapetis C, Singhal N, Roder D. Pancreatic cancer epidemiology and survival in an Australian population. Asian Pac J Cancer Prev. 2009;10(3):369-74.

23. Matheus AS, Montagnini AL, Jukemura J, Jurendini R, Penteado $S$, Abdo EE, Cunha JEM. Risk factors for pancreatic fistula. Does it have a clinical application for early identification of patients with high risk to develop pancreatic fistula after pancreaticoduodenectomy? Gastroenterol 2006;130(4) supl2.

24. Molina V, Visa L, Conill C, Navarro S, Escudero JM, Auge JM, Filella $X$, Lopez-Boado MA, Ferrer J, Fernandez-Cruz L, Molina R. CA 19-9 in pancreatic cancer: retrospective evaluation of patients with suspicion of pancreatic cancer. Tumor Biol, 2012. 33:799-807.

25. Muscat JE, Stellman SD, Hoffmann D, Wynder EL. Smoking and pancreatic cancer in men and women. Cancer Epidemiol Biomarkers Prev. 1997;6(1):15-9.
26. Rocha LCG, Queiroz FL, Eudes Magalhães EA, Santos FAV, Caldeira DAM, Ribas MA. Duodenopancreatectomia: Avaliação dos resultados em 41 pacientes. Rev. Col. Bras. Cir. 2006;33(6):38792.27. Secretan B, Straif K, Baan R, Grosse Y, El Ghissassi F, Bouvard V, Benbrahim-Tallaa L, Guha N, Freeman C, Galichet L, Cogliano C. A review of human carcinogens-Part E: tobacco, areca nut, alcohol, coal smoke, and salted fish. Lancet Oncol. 2009;10(11):1033-4.

28. Søreide K, Aagnes B, Møller B, Westgaard A, Bray F. Epidemiology of pancreatic cancer in Norway: trends in incidence, basis of diagnosis and survival 1965-2007. Scand J Gastroenterol. 2010;45(1):82-92.

29. Union for International Cancer Control - UICC. TNM Classification of Malignant Tumours -7th ed. 2010. [acesso em: 2012 Mar 15]. Disponível em: http://www.uicc.org/resources/tnm

30. Winter JM, Brennan MF, Tang LH, D'Angelica MI, Dematteo RP, Fong Y, Klimstra DS, Jarnagin WR, Allen PJ. Survival after Resection of Pancreatic Adenocarcinoma: Results from a Single Institution over Three Decades. Ann Surg Oncol [Internet]. 2011 Julho [Acesso em 2011 Ago 30];1900-3. Disponível em: http://www.ncbi.nlm.nih.gov/ pubmed/21761104 